\title{
Aspek Geodetik Penegasan Batas Darat Indonesia dan Papua New Guinea: Status dan Permasalahannnya
}

\author{
Silvester Sari Sai ${ }^{1)}$, Hasanuddin Z. Abidin ${ }^{1)} \&$ Sobar Sutisna ${ }^{2)}$ \\ ${ }^{1)}$ Departemen Teknik Geodesi, Institut Teknologi Bandung, \\ Jl.Ganesha 10 Bandung 40132 \\ ${ }^{2)}$ Pusat Pemetaan Batas Wilayah, Badan Koordinasi Survei dan Pemetaan Nasional \\ (BAKOSURTANAL), Jl. Raya Jakarta-Bogor Km.46, Cibinong, Bogor
}

\begin{abstract}
Abstrak. Permasalahan teknis batas darat Indonesia dan Papua New Guinea berkaitan dengan proses delimitasi dan demarkasi batas darat yang telah dilaksanakan oleh kedua negara. Proses tersebut tidak menyatakan secara tegas implementasi datum dan kerangka referensi yang digunakan untuk merekonstruksi monumen batas berdasarkan meridian yang disepakatai dalam artikel-1 perjanjian batas tahun 1973. Tidak jelasnya datum dari meridian kesepakatan mengakibatkan demarkasi batas dilakukan menggunakan datum yang berbeda yaitu datum astronomis dan geodetik. Penggabungan koordinat astronomis dan geodetik untuk merepresentasikan meridian kesepakatan menimbulkan permasalahan dan implikasi teknis bagi batas darat kedua negara. Makalah ini mengkaji status dan permasalahan teknis penegasan batas darat Indonesia dan Papua New Guinea dan alternatif solusinya. Kajian dilakukan menggunakan koordinat monumen batas hasil survei GPS tahun 2004 dan koordinat monumen batas perjanjian tahun 1973 serta hasil demarkasi tahun 1983-1991. Makalah ini ditutup dengan beberapa kesimpulan dan saran.
\end{abstract}

Kata kunci: Indonesia; Papua New Guinea; batas darat; datum dan kerangka bersama batas bersama.

\begin{abstract}
Technical problems of land boundary between Indonesia and Papua New Guinea are related to delimitation and demarcation process that has been done by two countries. The process did not explicitly the datum and reference frame being used in reconstructing of monuments border pursuant to the agreement of meridian in article-1 of boundary agreement of 1973. The uncertainty about the datum caused demarcation process has been done using different datum. The datums are astronomic and geodetic datum. The combination of the coordinate derives from respectively datum to reconstruct the agreement of meridian caused technical problems and implication to status of land boundary of both countries. This paper investigates about status and technical problems of land boundary between Indonesia and Papua New Guinea and its alternative solution. Investigation is done using the boundary monuments coordinate given by GPS survey of 2004 and boundary monuments coordinate pursuant to boundary agreement of 1973 and result of demarcation survey of 1983-1991. This paper is sum up with some conclusions and recommendation.
\end{abstract}

Makalah diterima redaksi tanggal 15 September 2005. 
Keywords: Indonesia; Papua New Guinea; land boundary; Common Border Datum and Reference Frame (CBDRF).

\section{Pendahuluan}

Batas darat antara Indonesia dan Papua New Guinea memanjang dari Skouw, Jayapura di sebelah utara sampai muara sungai Bensbach, Merauke di sebelah selatan dengan panjang garis batas sekitar \pm 860 Kilometer. Garis batas tersebut ditetapkan secara buatan (artificial) menggunakan meridian astronomis dan alami (natural) menggunakan thalweg sungai fly dan muara sungai Bensbach (Gambar 1). Reprensetatif garis batas tersebut dinyatakan dengan monumen meridian (MM) yang terdiri atas 52 monumen meridian batas dan perapatannya dimana 33 monumen meridian terdapat di segmen utara yang merepresentasikan meridian $141^{\circ} 00^{\prime} 00^{\prime}$ yang terdiri atas MM1 sampai MM10 dan 19 monumen meridian di segmen selatan yang merepresentasikan meridian $141^{\circ} 01^{\prime} 10^{\prime}$ yang terdiri atas MM11 sampai MM14.

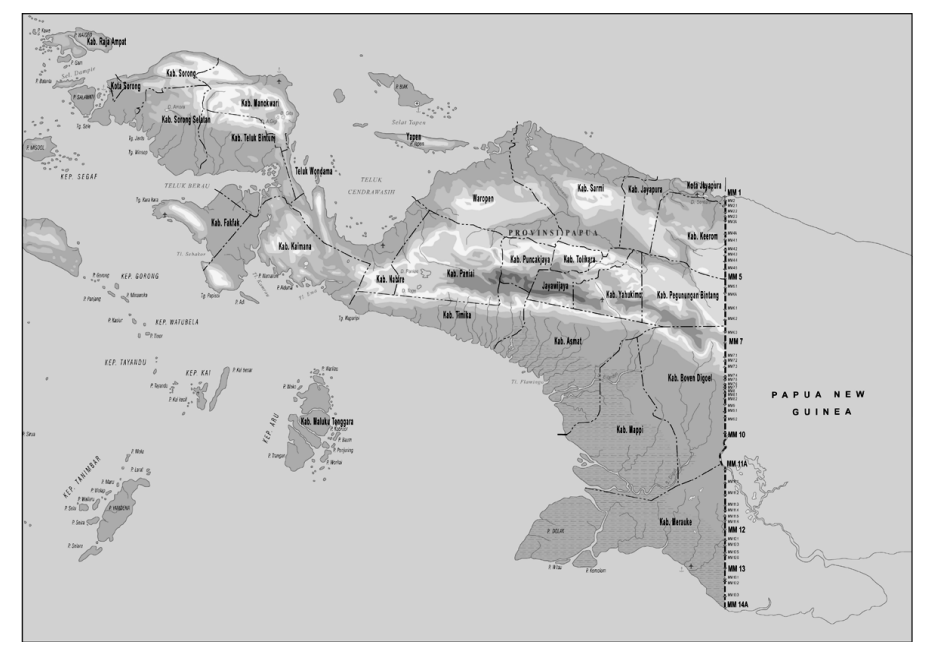

Gambar 1 Ilustrasi batas darat Indonesia dan Papua New Guinea.

Delimitasi batas darat Indonesia dan Papua New Guinea sebagaimana tertuang dalam perjanjian batas tertentu antara pihak Indonesia dan Australia pada tahun 1973 tidak menyatakan secara eksplisit implementasi datum dan kerangka referensi dari meridian $141^{\circ} 00^{\prime} 00^{\prime \prime}$ BT dan $141^{\circ} 01^{\prime} 10^{\prime \prime}$ BT sebagai batas artifisial kedua negara. Tidak jelasnya implementasi dari datum dan kerangka referensi tersebut menyebabkan kegiatan demarkasi batas darat Indonesia dan Papua New Guinea dilaksanakan menggunakan datum dan kerangka referensi yang berbeda yaitu datum dan kerangka referensi astronomis yang digunakan untuk merekonstruksi 14 buah monumen meridian batas (MM) serta datum dan kerangka referensi geodetik yang digunakan untuk merekonstruksi 38 buah 
monumen meridian batas perapatan (MMx.y). Secara teoritis koordinat yang diperoleh dari kedua datum tersebut akan berbeda oleh karena penyimpangan arah garis vertikal (vertical deflection) dari datum astronomis yang mengacu kepada normal geoid dan datum geodetik yang mengacu kepada normal ellipsoid. Penggabungan koordinat dari kedua datum tersebut untuk merepresentasikan meridian $141^{\circ} 00^{\prime} 00^{\prime \prime}$ BT dan $141^{\circ} 01^{\prime} 10^{\prime \prime}$ BT akan memberikan implikasi bagi status batas darat kedua negara. Berikut akan dijelaskaan mengenai status dan permasalahan batas darat Indonesia dan Papua New Guinea serta impikasinya dan dilanjutkan dengan alternatif solusi permasalahannya.

\section{Status dan Permasalahan Penegasan Batas Darat Indonesia dan Papua New Guinea}

\subsection{Status Penegasan Batas Darat Indonesia dan Papua New Guinea}

\subsubsection{Delimitasi Batas Darat Indonesia dan Papua New Guinea}

Berdasarkan konvensi tahun 1895 antara Belanda dan Inggris, pihak Indonesia dan Australia melakukan perundingan yang menghasilkan perjanjian antara Indonesia dan Australia mengenai garis-garis batas tertentu antara Indonesia dan Papua New Guinea pada tahun 1973. Secara lebih rinci batas darat antara Indonesia dan Papua New Guinea didefinisikan oleh Artikel-1 dari Perjanjian Batas tahun 1973 antara Australia dan Indonesia sebagai berikut:

ARTICLE 1
The boundary between Papua New Guinea and Indonesia on the island of New Guinea (Irian)
shall be more precisely demarcated as follows:
(a) In the north the boundary is the meridian of longitude $141^{\circ}$ East extending southwards
from the point of the intersection of the meridian with the mean low water line on the
northern coast, located at Latitude $2^{\circ} 35$ '37" South, to the point of its most northerly
intersection with the waterway ("thalweg") on the Fly River and that meridian shall be
deemed to lie along the geodesic lines successively linking the markers MM1, MM2,
MM3, MM4, MM5, MM6, MM7, MM8, MM9, and MM10 established by the Joint
Survey and indicated on the chart annexed to this Agreement.
(b) From the point of the most northerly intersection of the meridian of Longitude $141^{\circ}$
East with the waterway ("thalweg") of the Fly River (at present located at Latitude
$6^{\circ} 19$ '24" South) the boundary lies along that waterway to the point of its most southerly
intersection with the meridian of Longitude $141^{\circ} 01^{\prime} 10^{\prime}$ " East (at present located at
Latitude $6{ }^{\circ} 33^{\prime}$ " From the last- mentioned point the boundary is the meridian of
Longitude $141^{\circ} 01$ ' $10^{\prime}$ " East extending southwards to the point of Latitude $9^{\circ} 08^{\prime} 08^{\prime}$
South (Point B3 shown on the chart annexed to this Agreement) and that meridian shall
be deemed to lie along the geodesic lines successively linking the markers MM11,
MM12, MM13, MM14 established by the Joint Survey and indicated on the chart
annexed to this Agreement. South).


(c) From the last- mentioned point the boundary is the meridian of Longitude $141^{\circ} 01$ ' $10^{\prime \prime}$ East extending southwards to the point of Latitude $9^{\circ} 08^{\prime} 08^{\prime \prime}$ South (Point B3 shown on the chart annexed to this Agreement) and that meridian shall be deemed to lie along the geodesic lines successively linking the markers MM11, MM12, MM13, MM14 established by the Joint Survey and indicated on the chart annexed to this Agreement.

Selain artikel-1 tersebut terdapat artikel-9 dalam perjanjian batas tersebut yang isinya sebagai berikut:

\section{ARTICLE 9}

1. The co-ordinates of the points specified in this Agreement are geographical co-ordinates. The actual location of any points or lines referred to in this Agreement which have not yet been determined shall be determined by a method to be agreed upon by the competent authorities of the Government of Australia and the Government of Indonesia.

Berdasarkan artikel-1 dan artikel-9 tersebut diatas terdapat deskripsi umum batas darat Indonesia dan Papua New Guinea sebagai berikut:

a. Berdasarkan artikel-1 perjanjian batas tersebut diatas, representasi dari garis batas darat antara Indonesia dan Papua New Guinea meliputi 14 buah monumen meridian batas sebagai berikut :

1. dari MM1 sampai MM10 mengikuti meridian $141^{0} 00^{\prime} 00^{\prime \prime} \mathrm{BT}$

2. dari MM10 sampai MM11 mengikuti garis thalweg dari sungai Fly

3. dari MM11 sampai MM14 mengikuti meridian $141^{0} 01$ '10" BT

Garis yang mengubungkan ke-14 buah monumen batas tersebut adalah garis geodesik.

b. Pada artikel-9 ayat 1 dinyatakan bahwa letak/lokasi sebenarnya dari setiap titik (monumen batas) dan garis (garis geodesik yang menghubungkan antara titik/monumen batas MM) yang dinyatakan dalam perjanjian (yang berjumlah 14 buah titik/moumen batas) dan yang belum ditentukan (titik/monumen meridian perapatan) akan ditentukan dengan cara yang akan disetujui bersama oleh pejabat-pejabat yang berwenang dari Pemerintah Indonesia dan Australia.

\subsubsection{Demarkasi Batas Darat Indonesia dan Papua New Guinea}

Beberapa kegiatan demarkasi dilakukan oleh pihak Indonesia dan Australia serta Papua New Guinea sepanjang tahun 1966-1991 sebagai berikut:

\section{a. Survei Demarkasi Batas 1966-1967}

Untuk menindaklanjuti Konvensi tahun 1895 antara Belanda dan Inggris berkenan dengan batas wilayah kedua negara di New Guinea, pemerintah Indonesia dan Australia berdasarkan hasil pertemuan di Jakarta pada 31 Juli-4 Agustus 1964, sepakat untuk melakukan demarkasi batas darat antara Indonesia dan Papua New Guinea. Kesepakatan tersebut direalisasikan dengan survei 
demarkasi batas yang dilaksanakan dari tahun 1966 sampai dengan tahun 1967. Pada survei demarkasi tersebut didirikan 14 buah monumen meridian batas (MM), yaitu MM1, MM2, MM3, MM4, MM5, MM6, MM7, MM8, MM9, MM10, MM11, MM12, MM13 sampai MM14. Teknis penentuan posisi dari ke-14 monumen batas tersebut seperti terlihat pada gambar berikut:

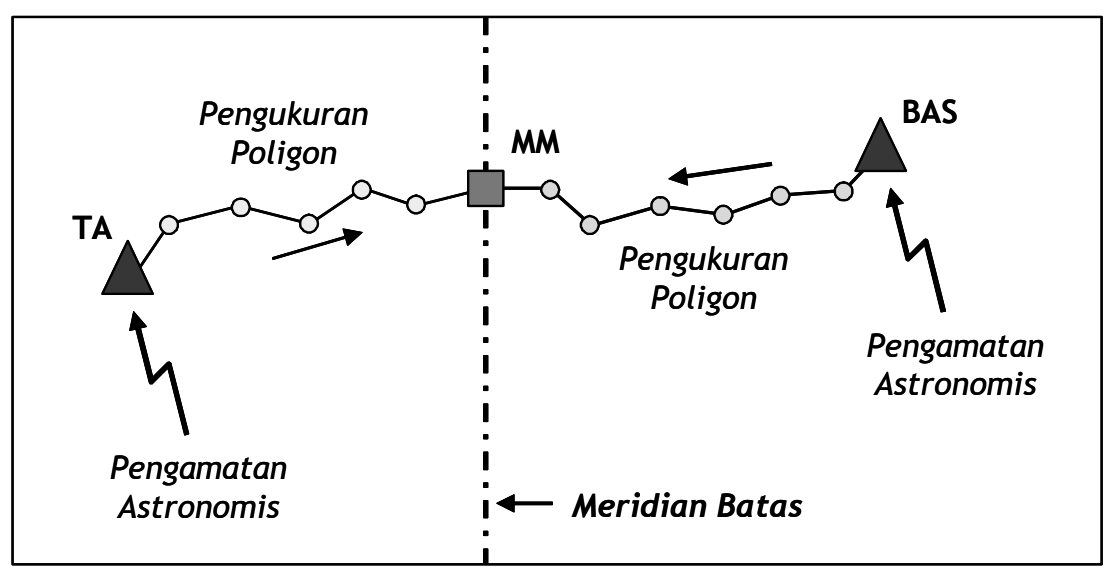

Gambar 2 Sketsa penentuan koordinat monumen meridian batas (MM).

Beberapa catatan berkenaan dengan datum dan kerangka referensi dari survei demarkasi tahun 1966-1967 sebagai berikut:

1) Survei demarkasi tahun 1966-1967 yang dilaksanakan oleh pihak Indonesia dan Australia telah menggunakan suatu datum dan kerangka referensi bersama yaitu datum dan kerangka referensi astronomis. Realisasi dari kerangka referensi astronomis tersebut berdasarkan posisi bintang $(\alpha, \delta)$ yang diperoleh dari kalender bintang APFS (Apparent Places of Fundamental Star). Koordinat geografis astronomis dari titik bantu astronomis TA (titik astronomi di pihak Indonesia) dan BAS (Boundary Astonomic Station di pihak Papua New Guinea) dinyatakan dalam sistem koordinat referensi geografis astronomis $(\Phi, \Lambda)$ yang geosentrik dimana sumbu rotasinya berdasarkan kutub menengah referensi yang didefenisikan oleh BIH (Bureau International de l'Heure) sebelum tahun 1968. Menurut Soenarjo keseluruhan posisi geografis astronomis $(\Phi, \Lambda)$ yang diperoleh sebelum tahun 1968 dikoreksikan kepada kutub menengah referensi yang didefenisikan oleh CIO tahun 1967 [Soenarjo,1978]. Perlu dicatat dalam menentukan koordinat suatu titik dipermukaan bumi diperlukan suatu kesepakatan mengenai arah dari sumbu-sumbu koordinat referensi. Salah satu arah sumbu koordinat referensi adalah menyatakan arah dari pergerakan kutub (polar motion), CIO (Conventional International origin) merupakan arah kutub referensi yang diperoleh dari posisi rata-rata pergerakan kutub sepanjang tahun 1900-1905 [Vanicek \& Krakiwsky, 
1986]. Hubungan antara nilai koordinat geografis astronomis $(\Phi, \Lambda)$ yang diperoleh sebelum tahun 1968 dalam hal ini bereferensikan terhadap BIH dinyatakan dalam referensi CIO tahun 1967 sebagai berikut [Seenarjo,1978]:

$$
\begin{aligned}
& \delta \Phi=-(\delta x \cdot \cos \Lambda-\delta y \cdot \sin \Lambda) \\
& \delta \Lambda=-(\delta x \cdot \sin \Lambda-\delta y \cdot \cos \Lambda)
\end{aligned}
$$

Perbedaan antara koordinat $\mathrm{CIO}$ dan koordinat $\mathrm{BIH}(\delta \Phi, \delta \Lambda)$ sebelum tahun 1968 dimuat dalam Annual Report BIH dalam bentuk [Soenarjo,1978 dan Heiskanen,W.H. \& Moritz,1967 ]:

$$
\begin{aligned}
& x_{C I O}-x_{B I H 19 \ldots . .}=\delta x \\
& y_{C I O}-y_{B I H 19 \ldots . .}=\delta y
\end{aligned}
$$

2) Koordinat dari ke-14 monumen meridian $(\mathrm{MM})$ batas tersebut merupakan koordinat (kuasi) astronomis geografis $(\Phi, \Lambda)$ yang diperoleh menggunakan poligon dari titik bantu astronomis (TA dan BAS). Sistem koordinat monumen meridian batas tersebut merupakan sistem koordinat geografis astronomis yang geosentrik dengan kutub menengah referensi didefenisikan oleh BIH sebelum tahun 1968 yang selanjutnya dikoreksikan terhadap kutub yang didefenisikan oleh CIO tahun 1967.

\section{b. Survei Demarkasi Batas 1983-1991}

Pada tahun 1982 suatu MOU (Memorandum of Understandings) antara Indonesia dan Papua New Guinea ditanda tangani untuk mengimplementasikan metode penentuan posisi dengan satelit Transit Doppler untuk pelaksanaan lebih lanjut survei demarkasi batas darat Indonesia dan Papua New Guinea [Rais,1988; Rais \& Villanueva,1993]. Pengukuran lapangan dengan metode survei satelit Transit Doppler dilaksanakan pada periode tahun 1983 sampai tahun 1989. Secara umum survei demarkasi batas dilaksanakan mulai dari MM14 bergerak ke arah utara sampai MM1. Sesudah survei demarkasi batas tersebut diperoleh secara keseluruhan 52 monumen meridian, dimana 33 monumen dianggap merepresentasikan meridian $141^{\circ} 00^{\prime} 00^{\prime \prime}$ BT sampai pertemuan dengan sungai Fly dan 19 monumen dianggap merepresentasikan meridian $141^{\circ} 01$ ' $10^{\prime \prime}$ BT sejak meninggalkan sungai Fly sampai pertemuan dengan mulut sungai Bensbach di pantai selatan. Untuk monumen meridian batas tambahan diluar ke-14 monumen meridian batas yang sudah ada, penomorannya dilakukan dengan menambahkan satu digit sesudah nomor monumen awalnya (MMx.y). Sebagai contoh monumen MM12.1 dan MM12.2 adalah monumen-monumen batas tambahan antara MM12 dan MM13. Disamping itu selama survei juga dibangun empat monumen baru untuk menggantikan monumen-monumen MM3, MM4, MM11 dan MM14 yang telah 
rusak atau hilang. Monumen meridian batas baru ini diberi nomor MM3A, MM4A, MM11A dan MM14A.

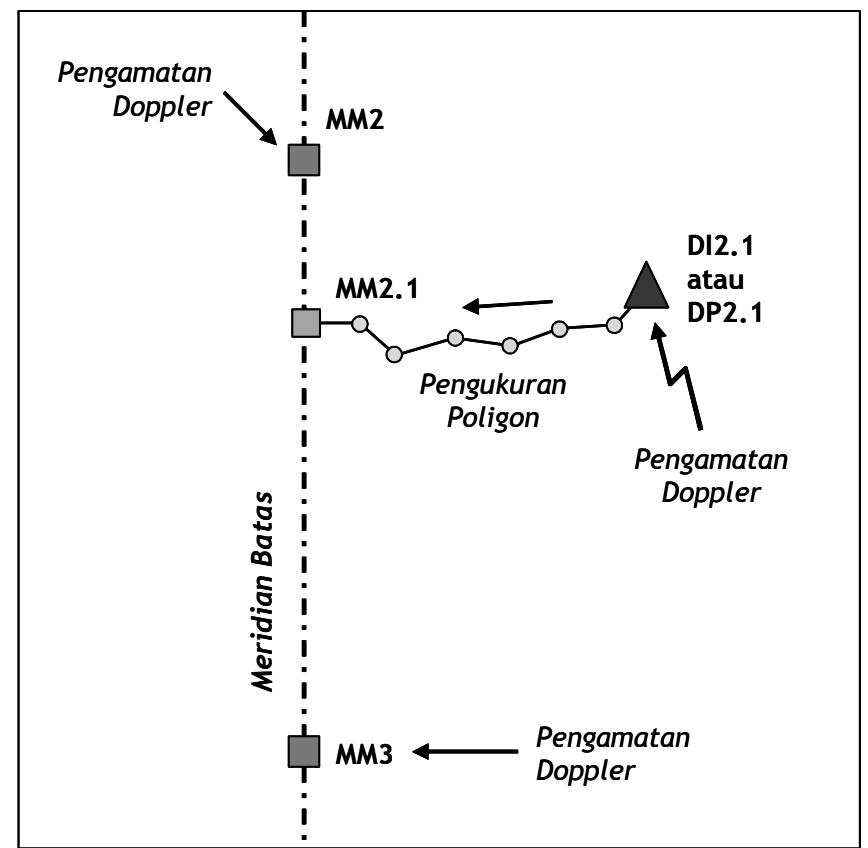

Gambar 3 Sketsa penentuan koordinat titik batas perapatan MM2.1.

Untuk MM1 sampai MM14 pengamatan satelit Doppler langsung dilakukan pada monumen batasnya. Sedangkan untuk monumen batas perapatan (MMx.y) pengamatan satelit Doppler tidak langsung diadakan diatas monumen tersebut, melainkan pada suatu titik bantu yang sengaja dipilih sedekat mungkin dengan garis batas (maksimum 500 meter). Dalam survei demarkasi tersebut titik bantu Doppler dari pihak Indonesia dinamakan DI (Doppler Indonesia) dan dari pihak Papua New Guinea dinamakan DP (Doppler PNG). Pengamatan satelit Doppler dilaksanakan di titik DI atau DP tersebut. Koordinat geodetik titik bantu DI atau DP ini terlebih dahulu ditransformasikan menjadi koordinat astronomis, menggunakan informasi nilai komponen defleksi vertikal yang diinterpolasi dari nilai-nilai komponen defleksi vertikal di kedua monumen meridian (MM) ujungnya. Berdasarkan koordinat astronomis dari titik DI atau DP ini, maka selanjutnya meridian $141^{\circ} 00^{\prime} 00^{\prime \prime} \mathrm{BT}$ atau $141^{\circ} 01^{\prime} 10^{\prime \prime} \mathrm{BT}$ direkonstruksi dengan pengukuran poligon (traverse), dan selanjutnya monumen meridian perapatan (MMx.y) ) didirikan pada meridian batas hasil rekonstruksi tersebut. Teknis penentuan koordinat monumen meridian batas survei seperti terlihat pada gambar 3. 
Beberapa catatan berkenaan dengan datum dan kerangka referensi dari survei demarkasi tahun 1983-1991 sebagai berikut:

1) Survei demarkasi tahun 1983-1991 yang dilaksanakan oleh pihak Indonesia dan Australia telah menggunakan suatu datum geodetik dengan kerangka yang berbeda. Datum geodetik tersebut menggunakan datum geodetik NSWC 9Z-3D (NWL 9-D/Naval Weapons Laboratory 9-D, USA) yang digunakan dalam penentuan posisi satelit Transit Doppler semenjak tahun 1977. Kerangka referensi yang digunakan Indonesia diantaranya menggunakan base stasiun Merauke (D 129) dan Biak (D 74) serta Sentani, sedangkan Papua New Guinea menggunakan base stasiun Aimbak dan Ningerum.

2) Oreantasi dari meridian referensi atau meridian nol (reference meridian/zero meridian) dari datum geodetik NSWC 9Z-3D tidak sejajar dengan meridian referensi yang dedefenisikan oleh BIH. Oleh karenanya meridian referensi tersebut tidak sejajar dengan meridian referensi yang digunakan untuk menyatakan koordinat astronomis monumen meridian (MM). Tidak sejajarnya meridian referensi tersebut menyebabkan rotasi pada komponen bujur sebesar 0.814 ". Oleh karena adanya rotasi tersebut maka secara teoritis akan mempengaruhi nilai koordinat geografis astronomis titik bantu Doppler (DI dan DP) serta nilai koordinat geografis astronomis dari monumen meridian perapatan (MMx.y).

3) Perlu dicatat bahwa semenjak tahun 1968 kutub referensi yang digunakan adalah kutub referensi menengah yang didefenisikan oleh CIO tahun 1967. Oleh karena rekonstruksi monumen meridian batas dilaksanakan pada tahun 1983-1991 maka nilai koordinat geografis astronomis yang diperoleh pada saat itu bereferensikan kepada kutub menengah CIO tahuin 1967.

4) Meskipun dengan metode satelit Doppler ini diperoleh koordinat geodetik dari monumen batas, tapi karena pada penentuan batas terdahulu menggunakan koordinat astronomis, maka koordinat-kordinat geodetik tersebut harus ditransformasikan menjadi koordinat astronomis menggunakan persamaan [Heiskanen, W. H. \& Moritz, 1967].

$$
\begin{aligned}
& \phi=\Phi-\xi \\
& \lambda=\Lambda-(\eta \cdot \sec \phi)
\end{aligned}
$$

dimana:

$$
\begin{aligned}
\phi & =\text { Lintang geodetik } \\
\lambda & =\text { Bujur geodetik } \\
\Phi & =\text { Lintang astronomis } \\
\Lambda & =\text { Bujur astronomis }
\end{aligned}
$$




\subsection{Permasalahan Penegasan Batas Darat Indonesia dan Papua New Guinea}

Permasalahan teknis batas darat Indonesia dan Papua New Guinea meliputi:

a. Isi perjanjian batas tahun 1973 tidak mencantumkan secara tegas implementasi sistem referensi koordinat (datum) dan kerangka referensi dari koordinat geografis ke-14 monumen meridian (MM) batas. Oleh karena realisasi awal menggunakan metode penentuan posisi astronomis yang menghasilkan koordinat geografis astronomis maka secara teoritis sistem referensi koordinat yang digunakan adalah sistem referensi koordinat astronomis dengan kerangka referensi dari koordinat bintang yang terdapat pada kalender bintang APFS (Apparent Places of Fundamental Stars).

b. Posisi astronomis dari ke-14 monumen meridian batas (MM) ditentukan secara tidak langsung dengan metode astro-geodetik, yaitu berdasarkan koordinat astronomis suatu titik bantu (TA dan atau BAS) yang selanjutnya direkonstruksi dengan metode poligon. Posisi astronomis dari ke-38 monumen meridian perapatan (MMx.y) ditentukan secara tidak langsung berdasarkan koordinat geodetik dengan metode satelit Doppler dari titik bantu (DI atau DP) yang selanjutnya direkonstruksi dengan metode poligon. Oleh Karena tingkat ketelitian kedua metode penentuan posisi tersebut berbeda dan tidak sejajarnya meridian referensi atau meridian nol datum geodetik NSWC 9Z-2 3D (NWL 9-D) serta pengaruh ketelitian interpolasi linear komponen defleksi vertikal yang berbeda untuk setiap monumen batas, maka koordinat astronomis dari kedua kelompok monumen batas tersebut secara teoritis akan berbeda dan secara spasial tidak homogen.. Oleh sebab itu keabsahan penggabungan kedua kelompok koordinat tersebut untuk merepresentasikan garis batas yang mempunyai nilai bujur sama pada meridian $140^{\circ} 00^{\prime} 00^{\prime \prime} \mathrm{BT}$ dan $141^{\circ} 01^{\prime} 10^{\prime \prime} \mathrm{BT}$ perlu dikaji ulang.

c. Isi perjanjian batas tahun 1973 artikel-1 menyatakan bahwa garis batas, selain sepanjang thalweg sungai Fly, adalah garis geodesik yang menghubungkan monumen batas MM1 sampai dengan MM14. Garis geodesik dapat didefinisikan sebagai jarak terdekat antara dua titik pada permukaan ellipsoid, yang merupakan kumpulan titik-titik dimana kelengkungan geodetiknya sama dengan nol [Torge, 1991]. Apabila mengacu pada isi perjanjian maka untuk keperluan rekonstruksi monumen batas (seandainya rusak) serta pembangunan monumen batas antara untuk keperluan perapatan, pengidentifikasian secara baik dari arah garis geodesik ini di lapangan bukanlah suatu hal yang mudah dan akan mengintrodusir permasalahan teknis tersendiri, terutama kalau kita mengingat permasalahan $\mathrm{b}$ dan $\mathrm{c}$ di atas.

d. Pada artikel-9 ayat 1 perjanjian batas tahun 1973 dinyatakan bahwa letak/lokasi sebenarnya dari setiap titik (monumen batas) dan garis (garis 
geodesik yang menghubungkan antara titik/monumen) yang dinyatakan dalam perjanjian (yang berjumlah 14 buah titik/moumen batas) dan yang belum ditentukan (titik/monumen perapatan) akan ditentukan dengan cara yang akan disetujui bersama oleh pejabat-pejabat yang berwenang dari Pemerintah Indonesia dan Australia. Bila kita meninjau kata letak/lokasi maka berkenaan dengan posisi dimana dalam perspektif geodetik posisi merupakan bagian yang dinyatakan oleh koordinat. Oleh karenanya interpretasi dari pasal-9 ayat 1 perjanjian batas Indonesia dan Australia bahwa keberadaan titik-titik batas (monumen meridian yang sejumlah 14 buah) adalah bersifat final. Interpretasi tersebut akan membingungkan mengingat sejarah penetapan batas darat Indonesia adalah menggunakan batas artifisial menggunakan meridian $141^{\circ} 00^{\prime} 00^{\prime \prime}$ dan $141^{\circ} 01^{\prime} 10^{\prime \prime}$ sebagaimana dinyatakan dalam arikel-1 perjanjian batas tahun 1973.

e. Teknis penetapan monumen batas ditentukan dan disepakati awalnya dalam sistem koordinat geografis astronomis, maka rekonstruksi monumen batas yang rusak atau hilang dengan menggunakan sistem penentuan yang umum digunakan saat ini seperti GPS, akan mempunyai permasalahan tersendiri, mengingat adanya perbedaan dalam sistem dan kerangka referensi antara koordinat GPS dengan yang digunakan oleh monumen batas. Meskipun masalah ini secara teoritis dapat diselesaikan dengan transformasi menggunakan nilai komponen defleksi vertikal, tetapi penentuan nilai komponen defleksi vertikal melalui pengukuran gaya berat di lapangan yang teliti untuk kawasan batas Indonesia dan Papua New Guinea bukanlah suatu hal yang mudah mengingat topografi kawasan perbatasan yang bergunung-gunung dan cukup variatif.

f. Kegiatan penataan dan pengawasan perbatasan menjadi tidak optimal oleh karena permasalahan teknis tersebut diatas. Sebagai contoh adanya perbedaan hasil ukuran di lapangan dengan hitungan di atas peta yang dipakai sebagai pedoman kerja lapangan di beberapa segmen batas, sehingga aktivitas pembangunan yang secara tidak sengaja melewati garis batas dapat terjadi. Selain itu adanya perbedaan interpretasi terhadap keberadaan lokasi beberapa segmen garis batas yang sebenarnya di lapangan antara pihak Indonesia dan pihak Papua New Guinea, karena adanya gap antara peta hasil foto udara blok 1 dan blok 2 pada pengukuran tahun 1966-1967.

\subsection{Solusi Alternatif Permasalahan Penegasan Batas Darat Indonesia dan Papua New Guinea}

Berdasarkan uraian status dan permasalahan penegasan batas darat Indonesia dan Papua New Guinea, permasalahan teknis batas darat Indonesia dan Papua New Guinea dapat dikelompokkan dalam dua permasalahan pokok yaitu: 
a. Permasalahan pokok berkaitan dengan delimitasi, delimitasi batas antara Indonesia dan Papua New Guinea yang mengacu kepada perjanjian batas tahun 1973 tidak secara tegas mencatumkan implementasi datum dan kerangka referensi yang digunakan dalam rekonstruksi monumen meridian batas berdasarkan meridian yang disepakati.

b. Permasalahan pokok berkaitan dengan demarkasi, demarkasi monumen meridian perapatan dilapangan secara teknis dilaksanakan menggunakan sistem dan kerangka referensi koordinat yang berbeda yaitu sistem dan kerangka referensi koordinat astronomis dan geodetik. Demarkasi monumen meridian batas tidak dilakukan secara langsung untuk merekonstruksi meridian kesepakatan melainkan menggunakan titik-titik bantu astronomis dan godetik serta dilakukan staking out menggunakan poligon.

Implikasi dari permasalahan pokok berkaitan dengan penegasan batas darat Indonesia dan Papua New Guinea tersebut diatas adalah sebagai berikut:

a. Monumen meridian batas darat Indonesia dan Papua New Guinea mempunyai ketelitian yang tidak homogen secara spasial dimana nilai ketelitiannya dipengaruhi oleh:

1) Tingkat ketelitian dari koordinat (kuasi) astronomis monumen meridian batas (MM), yang direkonstruksi dari titik bantu TA dan BAS yang berkisar antara \pm 0.27 " sampai \pm 1.26 " (satu sigma) atau sekitar \pm 8 sampai \pm 38 meter.

2) Tingkat ketelitian dari koordinat geodetik monumen meridian batas dan titik-titik bantu Doopler (DI,DP) yang diperoleh melalui penentuan posisi relatif dengan satelit Transit Doppler yang berada sekitar \pm 5 sampai \pm 10 meter bahkan lebih buruk dapat mencapai \pm 20 sampai \pm 30 meter tergantung kepada metode dan teknis pengamatan.

3) Tingkat ketelitian interpolasi dari nilai komponen defleksi vertikal dari koordinat geografis astronomis monumen meridian batas dan koordinat geodetik titik bantu Doppler yang berada pada level \pm 2 " sampai \pm 3 " atau sekitar \pm 60 sampai \pm 90 meter, oleh karenanya monumen meridian perapatan secara kuantitatif mempunyai ketelitian pada level tersebut yang secara spasial tidak homogen. Ketelitian koordinat astronomis dari monumen perapatan dipengaruhi pula secara sistematis oleh rotasi komponen bujur dari datum geodetik NSWC 9Z-2 3D (NWL 9-D) sebesar 0.814".

4) Tingkat ketelitian pengukuran poligon (staking out) pada saat rekonstruksi monumen meridian (MM) dan monumen meridian perapatan (MMx.y). Ketelitian dari metode pengukuran poligon tersebut berada pada level \pm 0.3 " atau sekitar \pm 9 meter dan dapat mempunyai nilai yang lebih rendah. Tingkat ketelitian tersebut akan dipengaruhi 
pula oleh jarak titik bantu astronomis dan Doppler terhadap monumen meridian dan monumen meridian perapatan.

b. Oleh karena tingkat ketelitian yang berbeda dari monumen meridian batas darat Indonesia dan Papua New Guinea, monumen meridian batas tersebut tidak terletak atau tidak merepresentasikan garis batas yang mempunyai nilai bujur sama pada meridian $140^{\circ} 00^{\prime} 00^{\prime \prime}$ BT atau $141^{\circ} 01^{\prime} 10^{\prime \prime}$ BT berdasarkan perjanjian batas tahun 1973. Seandainya ke-52 monumen meridian batas ditentukan kembali koordinatnya dengan metode survei GPS berketelitian tinggi dan selanjutnya koordinat geodetiknya ditransformasikan ke koordinat astronomis, maka ke-52 monumen meridian batas yang telah ada tersebut tidak akan terletak pada meridian astronomis $141^{\circ} 00$ '00" BT untuk monumen meridian MM1 sampai MM10 dan juga tidak pada meridian astronomis $141^{\circ} 01^{\prime} 10^{\prime \prime}$ BT untuk monumen meridian MM11 sampai MM14. Seandainya jika tidak ditransformasikan ke sistem koordinat astronomis, maka ke-52 monumen meridian batas tersebut juga tidak akan terletak pada meridian geodetik $141^{\circ} 00^{\prime} 00^{\prime \prime}$ BT untuk monumen meridian MM1 sampai MM10 dan juga tidak pada meridian geodetik $141^{0} 01^{\prime} 10^{\prime \prime}$ untuk monumen meridian MM11 sampai MM14A.

Berdasarkan keadaan demikian maka terdapat dua entitas pertanyaan berkaitan dengan solusi alternatif permasalahan teknis penegasan batas darat Indonesia dan Papua New Guinea yaitu:

1) Apakah tetap mempertahankan keberadaan monumen meridian batas yang telah disepakati pada perjanjian tahun 1973 walaupun tidak merepresentasikan meridian yang disepakati?

2) Apakah tetap menggunakan meridian astronomis yang disepakati yaitu $141^{\circ} 00^{\prime} 00^{\prime \prime}$ dan $141^{\circ} 01^{\prime} 10^{\prime \prime}$ sesuai perjanjian tahun 1973 ?

Dari entitas pertanyaan tersebut terdapat dua solusi alternatif yang dapat dilakukan dalam kerangka penyelesaian permasalahan teknis tersebut sebagai berikut:

a. Seandainya jawaban ya disepakati untuk pertanyaan (1) maka perjanjian tahun 1973 perlu dilakukan amandemen. Kalau ini yang disepakati maka untuk setiap monumen meridian batas yang sudah ada, disamping koordinat astronomisnya, juga dicantumkan koordinat geodetiknya dalam datum WGS84.

b. Seandainya jawaban ya disepakati untuk pertanyaan (2) maka perlu dilaksanakan survei demarkasi batas ulang untuk merelokasi monumen meridian batas ke posisinya yang baru. Dalam kasus ini pun perlu diklarifikasi dan disepakati bersama, apakah meridian yang disebutkan dalam perjanjian tahun 1973 meridian astronomis atau meridian geodetik, dan juga perlu disepakati tentang datum dan tipologi kerangka yang akan digunakan. 


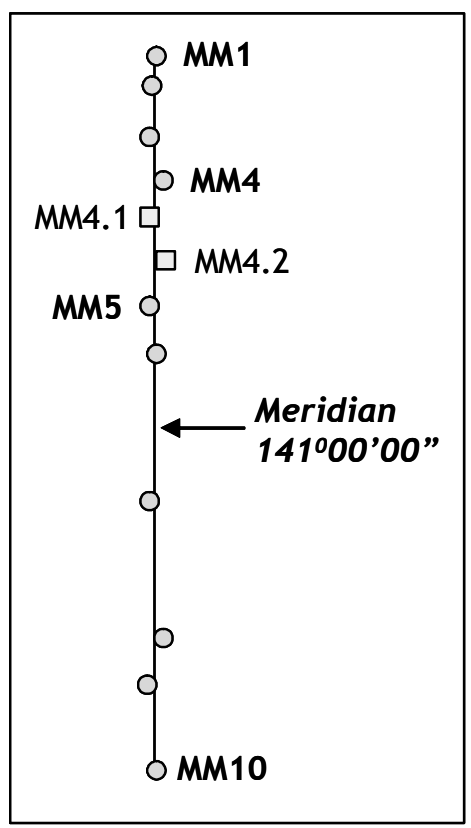

Gambar 4 Ilustrasi pergeseran titik batas Indonesia-Papua New Guinea.

Penegasan batas darat Indonesia dan Papua New Guinea telah memasuki babak baru berdasarkan kesepakatan sub-komite bersama bidang teknik (Joint Technical Sub-Committee) bertempat di Jayapura bulan Agustus tahun 2004. Kesepakatan tersebut berkenaan dengan rencana penggunaan datum dan kerangka bersama (Common Border Datum and Reference Frame) ITRF2000/WGS84 sebagai sebuah penanganan solusi atas permasalahan teknis batas darat antara kedua negara dalam kerangka kepentingan penataan dan pengawasan wilayah perbatasan.

Pada bab berikut akan diuraikan hal-hal yang berkenaan dengan datum dan kerangka referensi bersama (Common Border Datum and Reference Frame/CBDRF) diantaranya rancangan kerangka dan spesifikasi teknis serta kegiatan survei demarkasi batas menggunakan datum dan kerangka referensi bersama yang dilaksanakan pada 8 sampai dengan 20 September 2004 .

\section{Datum dan Kerangka Referensi Batas Bersama (Common Border Datum and Reference Frame/CBDRF)}

\subsection{Uraian Datum dan Kerangka Referensi Batas Bersama (Common Border Datum and Reference Frame/CBDRF)}

Datum dan kerangka referensi batas bersama (Common Border Datum and Reference Frame /CBDRF) adalah suatu datum dan kerangka referensi yang 
disetujui kedua belah pihak untuk digunakan dalam pengelolaan wilayah perbatasan nasional khususnya yang terkait dengan data dan informasi spasial. Secara praktis CBDRF direpresentasikan di lapangan dengan beberapa titik (tugu, monumen, pilar) kerangka yang koordinatnya diketahui dengan tingkat ketelitian tinggi dalam datum bersama yang disepakati oleh negara-negara yang berbatasan.

Dalam penataan batas antar negara ada beberapa alasan yang dapat dikemukakan tentang pentingnya datum bersama untuk kegiatan penentuan posisi serta survei pemetaan, yaitu:

a. Untuk memberikan sistem dan kerangka koordinat referensi yang seragam dan konsisten untuk keperluan pengadaan data dan informasi spasial, baik berupa koordinat titik-titik batas, peta batas, maupun sistem informasi batas.

b. Dengan adanya data dan informasi spasial batas yang mengacu pada suatu datum bersama yang terdefinisi secara baik dan akurat, maka:

1) Konflik batas dapat diminimalkan, dan

2) Manajemen kawasan perbatasan dapat optimal dan efisien

c. Karena mengacu pada datum yang telah disepakati bersama, pekerjaan survei pemetaan batas dapat dibuat lebih fleksibel, tanpa tergantung waktu dan siapa yang melaksanakan.

d. Memudahkan penyelesaian konflik perbatasan yang terkait dengan tanggung jawab menyangkut data dan informasi keruangan (spasial), seandainya terjadi peremajaan (updating) data dan informasi spasial yang terkait dengan kawasan perbatasan.

\subsection{Pendefinisian Datum dan Kerangka Referensi Batas Bersama Indonesia dan Papua New Guinea}

Berdasarkan penjelasan terhadap permasalahan batas darat Indonesia dan Papua New Guinea, maka pendefinisian suatu datum batas bersama (Common Border Datum) beserta kerangka referensi batas bersama (Common Border Reference Frame) di lapangan adalah suatu hal yang penting dan perlu direalisasikan segera. Dalam pendefinisian datum batas bersama antara Indonesia dan Papua New Guinea ada beberapa hal yang perlu diperhatikan yaitu:

a. Datum batas bersama yang baru harus disepakati oleh kedua pihak, Indonesia dan Papua New Guinea, relatif akurat, tidak bersifat lokal dan relatif mudah untuk direalisasikan.

b. Datum batas bersama yang digunakan sebaiknya datum geosentrik, bersifat global, paling modern dan dikenal secara luas.

c. Datum batas bersama yang baru dapat menggantikan secara baik datum yang didefinisikan secara tidak langsung oleh metode astro-geodetik serta datum yang digunakan oleh metode satelit Doppler sebelumnya. 


\subsection{Survei CBDRF 2004}

Dalam rangka rencana penggunaan datum dan kerangka batas bersama antara Indonesia dan Papua New Guinea dilaksanakan survei penentuan posisi geodetik titik-titik batas MM12.1 sampai dengan MM14A dalam sistem referensi koordinat geodetik WGS84 dengan kerangka ITRF2000. Kegiatan survei dilaksanakan pada 8 sampai 20 September 2004. Berikut akan diuraikan berkenaan dengan kegiatan survei tersebut.

\subsubsection{Kerangka Referensi Survei CBDRF 2004}

Kerangka yang digunakan dalam survei CBDRF 2004 adalah sebagai berikut:

Tabel 1 Tipologi stasion CBDRF yang digunakan dalam survei CBDRF 2004.

\begin{tabular}{|c|c|l|}
\hline Tipe & Stasion & \multicolumn{1}{|c|}{ Fungsi } \\
\hline Titik-titik IGS & TOW2, JAB1, & $\begin{array}{l}\text { Sebagai kerangka referensi utama untuk } \\
\text { merealisasikan sistem referensi koordinat } \\
\text { BGSO }\end{array}$ \\
\hline $\begin{array}{c}\text { Titik-titik Kerangka } \\
\text { GPS Orde-0 dari RI, } \\
\text { serta titik-titik Doppler }\end{array}$ & $\begin{array}{c}\text { N6001 (Jayapura), } \\
\text { N604A (Merauke) }\end{array}$ & $\begin{array}{l}\text { Mendekatkan untuk CBDRF } \\
\text { kerangka referensi WGS84/ITRF2000 ke } \\
\text { kawasan perbatasan RI-PNG }\end{array}$ \\
\hline Titik-titik batas RI-PNG & MM12.1 s/d & $\begin{array}{l}\text { Menghubungkan kerangka referensi } \\
\text { koordinat WGS84/ITRF2000 dengan } \\
\text { kerangka referensi koordinat astro-geodetik } \\
\text { Mang digunakan dalam penentuan batas RI- } \\
\text { PNG sebelumnya }\end{array}$ \\
\hline
\end{tabular}

\subsubsection{Spesifikasi Teknis Survei CBDRF 2004}

Spesifikasi teknis kegiatan survei CBDRF tahun 2004 sebagai berikut:

Tabel 2 Spesifikasi pengamatan GPS yang digunakan dalam survei CBDRF 2004.

\begin{tabular}{|l|l|}
\hline \multicolumn{1}{|c|}{ Parameter } & \multicolumn{1}{c|}{ Spesifikasi } \\
\hline Tipe receiver GPS & LEICA SR520 dengan tipe antena AT502 \\
\hline Lama sesi pengamatan & Titik IGS kontinyu, Titik N6001 (Jayapura) dan \\
& $\begin{array}{l}\text { N6004A (Merauke) minimum 24 jam, Titik } \\
\text { MM12.1 s/d MM14A minimum 12 Jam }\end{array}$ \\
\hline Ketelitian & $\begin{array}{l}\text { Titik IGS, Titik N6001 dan N6004A }<5 \mathrm{~cm}, \text { Titik } \\
\text { MM12.1 s/d MM14A }<10 \mathrm{~cm}\end{array}$ \\
\hline Interval data pengamatan & 30 detik \\
\hline Mask Angle & $15^{0}$ \\
\hline Pengamatan parameter meteorologis & Tidak dilakukan \\
\hline Pengukuran tinggi antenna & Di awal dan di akhir sesi pengamatan \\
\hline
\end{tabular}


Tabel 3 Spesifikasi pengolahan data GPS yang digunakan dalam survei CBDRF 2004.

\begin{tabular}{|l|l|}
\hline \multicolumn{1}{|c|}{ Parameter } & \multicolumn{1}{c|}{ Spesifikasi } \\
\hline Perangkat lunak GPS & Perangkat lunak ilmiah BERNESE 4.2 \\
\hline Format data untuk distribusi & RINEX \\
\hline Format solusi untuk distribusi & SINEX \\
\hline Tipe orbit yang digunakan & Precise ephemerides \\
\hline Pereduksian kesalahan orbit & Differencing, penggunaan precise ephemerides \\
\hline Pereduksian bias ionosfir & Kombinasi linear data fase \\
\hline Pereduksian bias troposfir & Estimasi \\
\hline $\begin{array}{l}\text { Pereduksian efek kesalahan } \\
\text { terkait antena }\end{array}$ & Koreksi pusat antena (fase antena) \\
\hline
\end{tabular}

\section{Analisis Aspek Geodetik Terhadap Solusi Alternatif Penyelesaian Permasalahan Batas Darat Indonesia dan Papua New Guinea}

Berkenaan dengan analisis yang akan dilakukan menggunakan data survei CBDRF tahun 2004 meliputi monumen meridian MM13 dan MM14A (berdasarkan perjanjian batas 1973 dan survei demarkasi 1966-1967) dan monumen batas perapatan meliputi MM12.1, MM12.2, MM12.3, MM12.4, MM12.5, MM12.6, MM13.1, MM13.2 dan MM13.3 (survei demarkasi 19831991), maka solusi alternatif yang akan dianalisis adalah sebagai berikut:

1) Tetap mempertahankan keberadaan titik-titik batas fisik MM12.1, MM12.2, MM12.3, MM12.4, MM12.5, MM12.6, MM13, MM13.1, MM13.2, MM13.3 dan MM14A (Solusi Alternatif I).

2) Tetap menggunakan meridian yang disepakati sesuai perjanjian tahun 1973 yakni dan $141^{\circ} 01$ "10" BT (Solusi Alternatif II).

Berdasarkan dua solusi alternatif tersebut untuk kepentingan analisis akan dibuat beberapa asumsi yang akan dibandingkan sebagai berikut:

a. Asumsi (a) tetap mempertahankan keberadaan titik-titik batas fisik di lapangan dengan koordinat geodetik yang diperoleh dari hasil survei CBDRF 2004 (Solusi Alternatif 1).

b. Asumsi (b) menggunakan koordinat geografis astronomis kesepakatan $141^{\circ} 01$ '10" BT sebagai koordinat geodetik dalam datum WGS84 menggunakan nilai komponen defleksi vertikal $=0$ (Solusi Alternatif 2).

c. Asumsi (c) menggunakan koordinat geografis astronomis kesepakatan $141^{\circ} 01^{\prime} 10^{\prime \prime}$ BT sebagai koordinat geodetik dalam datum WGS84 menggunakan nilai komponen defleksi vertikal model EGM1996 (Solusi Alternatif 2). 


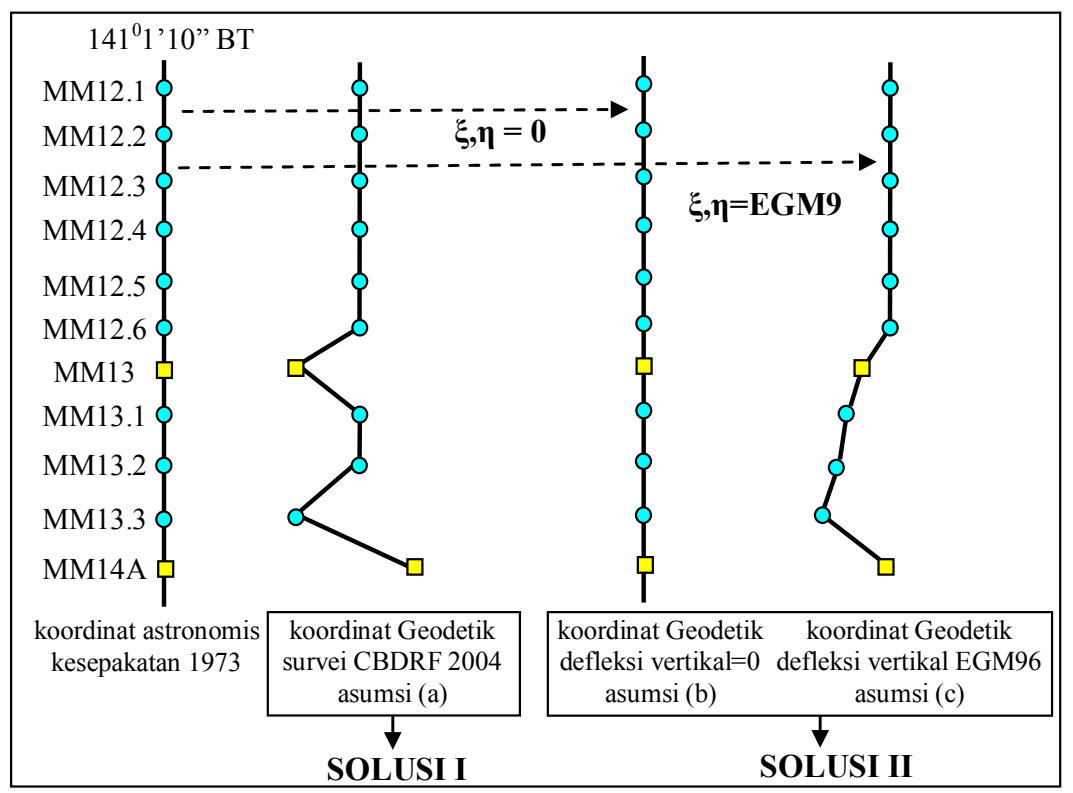

Gambar 5 Ilustrasi perbandingan penggunaan asumsi-asumsi solusi altermatif penyelesaian permasalahan batas darat Indonesia dan Papua New Guinea.

Beberapa hal yang perlu dicatat berkenaan dengan perbandingan asumsi tersebut dikemukakan sebagai berikut:

a. Analisis dilakukan didasarkan pada pemikiran bahwa penggunaan datum dan kerangka referensi yang berbeda serta tingkat ketelitian yang tidak homogen pada saat rekonstruksi monumen meridan (MM) dan monumen meridian perapatan (MMx.y), menyebabkan posisi monumen meridian batas dan monumen meridian perapatan tidak merepresentasikan meridian $141^{\circ} 01^{\prime} 10^{\prime \prime}$ BT. Untuk menghitung pergeseran monumen meridian batas dan perapatannya terhadap meridian kesepakatan $141^{\circ} 01^{\prime} 00^{\prime \prime}$ BT ditetapkan syarat batas sebagai berikut:

$$
\begin{aligned}
& \phi_{\text {WGS } 84 \text { kesepakatan }}=\Phi_{\text {kesepakatan }}-\xi \text { dan } \phi_{\text {WGS84 kesepakatan }}=\phi_{C B D R F 2004} \\
& \lambda_{\text {WGS84 kesepakatan }}=\Lambda_{\text {kesepakatan }}-\left(\eta \cdot \sec \phi_{\text {WGS84 }}\right) \text { dan } \\
& \lambda_{\text {WGS84 kesepakatan }}=\lambda_{\text {CBDEF } 2004}
\end{aligned}
$$

Syarat tersebut dapat dinyatakan bahwa koordinat geodetik monumen meridian batas kesepakatan ( $\left.\phi_{\text {WGS84 kesepakatan }}, \lambda_{\text {WGS84 kesepakatan }}\right)$ dalam datum WGS84 yang diperoleh dari koordinat geografis astronomis $\left(\Phi_{\text {kesepakatan }}, \Lambda_{\text {kesepakatan }}\right)$ kesepakatan hasil reduksi menggunakan komponen defleksi vertikal asumsi $=0$ dan model EGM96 akan mempunyai koordinat 
geodetik yang sama dengan koordinat koordinat geodetik monumen meridian batas hasil survei CBDRF 2004 dalam datum WGS84. Perlu dicatat EGM (Earth Gravitational Model) 1996 adalah model harmonik bola dari potensial gravitasi. Model tersebut disusun oleh koefisienkoefisien harmonik bola yang lengkap sampai derajat (n) dan orde (m). Dengan menggunakan nilai koefisien harmonik bola tersebut nilai komponen defleksi vertikal selanjutnya ditentukan menggunakan persamaan harmonik bola [NIMA,2000 dan NASA/GSFC,2004].

b. Dalam perhitungan koordinat kartesian geosentrik datum WGS84 dari koordinat astronomis kesepakatan, nilai komponen tinggi tidak digunakan atau dengan kata lain monumen meridian batas diasumsikan berada diatas permukaan ellipsoid referensi atau $\mathrm{h}_{\text {monumen batas }}=0$.

Nilai koordinat geodetik (WGS84) dan koordinat proyeksi UTM (Zone 54S) dari masing-masing asumsi dapat dilihat pada tabel berikut:

Tabel 4 Koordinat Geodetik (WGS84) dan Proyeksi UTM (Zone 54S) monumen meridian batas MM12.1 sampai MM14A asumsi (a).

\begin{tabular}{|l|c|c|c|c|}
\hline \multirow{2}{*}{ No Titik } & \multicolumn{2}{|c|}{ Koordinat Geodetik (WGS84) } & \multicolumn{2}{c|}{$\begin{array}{c}\text { Koordinat Proyeksi UTM } \\
\text { (Zone 54S) }\end{array}$} \\
\cline { 2 - 5 } & Lintang & Bujur & $\begin{array}{c}\text { Northing } \\
\text { (meter) }\end{array}$ & $\begin{array}{c}\text { Easting } \\
\text { (meter) }\end{array}$ \\
\hline MM12.1 & $8^{\circ} 00^{\prime} 47.340^{\prime \prime} \mathrm{S}$ & $141^{\circ} 01^{\prime} 09.271^{\prime \prime} \mathrm{E}$ & 9114248.322 & 502120.380 \\
MM12.2 & $8^{\circ} 02^{\prime} 34.369^{\prime \prime} \mathrm{S}$ & $141^{\circ} 01^{\prime} 09.270^{\prime \prime} \mathrm{E}$ & 9110961.592 & 502120.203 \\
MM12.3 & $8^{\circ} 04^{\prime} 06.456^{\prime \prime} \mathrm{S}$ & $141^{\circ} 01^{\prime} 09.238^{\prime \prime} \mathrm{E}$ & 9108133.717 & 502119.087 \\
MM12.4 & $8^{\circ} 07^{\prime} 43.858^{\prime \prime} \mathrm{S}$ & $141^{\circ} 01^{\prime} 09.146^{\prime \prime} \mathrm{E}$ & 9101457.519 & 502115.961 \\
\hline MM12.5 & $8^{\circ} 11^{\prime} 56.656^{\prime \prime} \mathrm{S}$ & $141^{\circ} 01^{\prime} 09.118^{\prime \prime} \mathrm{E}$ & 9093694.362 & 502114.728 \\
MM12.6 & $8^{\circ} 13^{\prime} 32.975^{\prime \prime} \mathrm{S}$ & $141^{\circ} 01^{\prime} 09.102^{\prime \prime} \mathrm{E}$ & 9090736.480 & 502114.117 \\
MM13 & $8^{\circ} 25^{\prime} 42.658^{\prime \prime} \mathrm{S}$ & $141^{\circ} 01^{\prime} 08.972^{\prime \prime} \mathrm{E}$ & 9068328.471 & 502109.059 \\
MM13.1 & $8^{\circ} 36^{\prime} 17.217^{\prime \prime} \mathrm{S}$ & $141^{\circ} 01^{\prime} 09.422^{\prime \prime} \mathrm{E}$ & 9048841.435 & 502121.833 \\
MM13.2 & $8^{\circ} 38^{\prime} 45.378^{\prime \prime} \mathrm{S}$ & $141^{\circ} 01^{\prime} 09.508^{\prime \prime} \mathrm{E}$ & 9044291.447 & 502124.224 \\
MM14A & $8^{\circ} 52^{\prime} 28.138^{\prime \prime} \mathrm{S}$ & $141^{\circ} 01^{\prime} 08.495 " \mathrm{E}$ & 9019024.544 & 502091.984 \\
\hline
\end{tabular}

Tabel 5 Koordinat Geodetik (WGS84) dan Proyeksi UTM (Zone 54S) monumen meridian batas MM12.1 sampai MM14A asumsi (b).

\begin{tabular}{|c|c|c|c|c|}
\hline \multirow{2}{*}{ No Titik } & \multicolumn{2}{|c|}{ Koordinat Geodetik (WGS84) } & \multicolumn{2}{|c|}{$\begin{array}{c}\text { Koordinat Proyeksi UTM } \\
\text { (Zone 54S) }\end{array}$} \\
\cline { 2 - 5 } & Lintang & Bujur & $\begin{array}{c}\text { Northing } \\
\text { (meter) }\end{array}$ & $\begin{array}{c}\text { Easting } \\
\text { (meter) }\end{array}$ \\
\hline MM12.1 & $8^{\circ} 00^{\prime} 48^{\prime \prime} \mathrm{S}$ & $141^{\circ} 01^{\prime} 10^{\prime \prime} \mathrm{E}$ & 9114228.080 & 502142.689 \\
MM12.2 & $8^{\circ} 02^{\prime} 36^{\prime \prime} \mathrm{S}$ & $141^{\circ} 01^{\prime} 10^{\prime \prime} \mathrm{E}$ & 9110911.528 & 502142.533 \\
MM12.3 & $8^{\circ} 04^{\prime} 08^{\prime \prime} \mathrm{S}$ & $141^{\circ} 01^{\prime} 10^{\prime \prime} \mathrm{E}$ & 9108086.307 & 502142.399 \\
MM12.4 & $8^{\circ} 07^{\prime} 45^{\prime \prime} \mathrm{S}$ & $141^{\circ} 01^{\prime} 10^{\prime \prime} \mathrm{E}$ & 9101422.482 & 502142.086 \\
MM12.5 & $8^{\circ} 11^{\prime} 58^{\prime \prime} \mathrm{S}$ & $141^{\circ} 01^{\prime} 10^{\prime \prime} \mathrm{E}$ & 9093653.095 & 502141.708 \\
\hline
\end{tabular}




\begin{tabular}{|l|l|l|l|l|}
\hline MM12.6 & $8^{\circ} 13^{\prime} 33^{\prime \prime} \mathrm{S}$ & $141^{\circ} 01^{\prime} 10^{\prime \prime} \mathrm{E}$ & 9090735.731 & 502141.566 \\
MM13 & $8^{\circ} 25^{\prime} 45^{\prime \prime} \mathrm{S}$ & $141^{\circ} 01^{\prime} 10^{\prime \prime} \mathrm{E}$ & 9068256.557 & 502140.461 \\
MM13.1 & $8^{\circ} 36^{\prime} 19^{\prime \prime} \mathrm{S}$ & $141^{\circ} 01^{\prime} 10^{\prime \prime} \mathrm{E}$ & 9048786.698 & 502139.482 \\
MM13.2 & $8^{\circ} 38^{\prime} 47^{\prime \prime} \mathrm{S}$ & $141^{\circ} 01^{\prime} 10^{\prime \prime} \mathrm{E}$ & 9044241.657 & 502139.253 \\
MM13.3 & $8^{\circ} 52^{\prime} 29^{\prime \prime} \mathrm{S}$ & $141^{\circ} 01^{\prime} 10^{\prime \prime} \mathrm{E}$ & 9018998.077 & 502137.944 \\
MM14A & $9^{\circ} 07^{\prime} 34^{\prime \prime} \mathrm{S}$ & $141^{\circ} 01^{\prime} 10^{\prime \prime} \mathrm{E}$ & 8991205.220 & 502136.470 \\
\hline
\end{tabular}

Tabel 6 Koordinat Geodetik (WGS84) dan Proyeksi UTM (zone 54S) monumen meridian batas MM12.1 sampai MM14A asumsi (c).

\begin{tabular}{|c|c|c|c|c|}
\hline \multirow{2}{*}{ No Titik } & \multicolumn{2}{|c|}{ Koordinat Geodetik (WGS84) } & \multicolumn{2}{|c|}{$\begin{array}{c}\text { Koordinat Proyeksi UTM } \\
\text { (Zone 54S) }\end{array}$} \\
\hline & Lintang & Bujur & $\begin{array}{l}\text { Northing } \\
\text { (meter) }\end{array}$ & $\begin{array}{l}\text { Easting } \\
\text { (meter) }\end{array}$ \\
\hline MM12.1 & $8^{0} 00,51.609 " \mathrm{~S}$ & $141^{0} 01 ' 12.61 ” \mathrm{E}$ & 9114117.228 & 502222.737 \\
\hline MM12.2 & $8^{0} 02,39.561 " \mathrm{~S}$ & $141^{0} 01 ' 12.67 ” \mathrm{E}$ & 9110802.140 & 502224.553 \\
\hline MM12.3 & $8^{0} 04 ' 11.519 " \mathrm{~S}$ & $141^{0} 01 ' 12.73 " \mathrm{E}$ & 9107978.238 & 502225.967 \\
\hline MM12.4 & $8^{0} 07$ ' 48.416" S & $141^{0} 01 ' 12.82 ” \mathrm{E}$ & 9101317.553 & 502228.412 \\
\hline MM12.5 & $8^{0} 12^{\prime} 01.302^{\prime \prime} \mathrm{S}$ & $141^{0} 01 ' 12.85 " \mathrm{E}$ & 9093551.680 & 502228.976 \\
\hline MM12.6 & $8^{0} 13,36.262 " \mathrm{~S}$ & $141^{0} 01 ' 12.83 ” \mathrm{E}$ & 9090635.542 & 502228.381 \\
\hline MM13 & $8^{0} 25^{\prime} 48.048 " \mathrm{~S}$ & $141^{0} 011^{\prime} 12.18 ” \mathrm{E}$ & 9068162.922 & 502207.354 \\
\hline MM13.1 & $8^{0} 36^{\prime} 21.905^{\prime \prime} \mathrm{S}$ & $141^{0} 01 ' 11.09 " \mathrm{E}$ & 9048697.468 & 502172.836 \\
\hline MM13.2 & $8^{0} 38^{\prime} 49.941 " \mathrm{~S}$ & $141^{0} 01 ' 10.08 ” \mathrm{E}$ & 9044151.327 & 502141.802 \\
\hline MM13.3 & $8^{0} 52,31.795 " \mathrm{~S}$ & $141^{0} 01 ' 10.06 " \mathrm{E}$ & 9018912.238 & 502138.144 \\
\hline MM14A & $9^{0} 07 \cdot 36.745 " \mathrm{~S}$ & $141^{0} 01 ' 10.65 ” \mathrm{E}$ & 8991120.907 & 502156.424 \\
\hline
\end{tabular}

\subsection{Menghitung Pergeseran Monumen Meridian Batas}

Berdasarkan koordinat geodetik WGS84 dan koordinat proyeksi UTM (Zone 54S) dari masing-masing asumsi seperti terlihat pada tabel (V.1,V.3 dan V.5) berikut akan dihitung pergeseran monumen meridian batas MM12.1 sampai MM14A dari perbandingan masing-masing asumsi sebagai berikut:

\section{a. Asumsi (a) dengan asumsi (b)}

Apabila dibandingkan nilai koordinat geodetik asumsi (a) yang diperoleh dari survei CBDRF 2004 dengan nilai koordinat geodetik asumsi (b) terdapat pergeseran monumen meridian batas karena koordinat geodetik yang diperoleh dari survei CBDRF 2004 tidak terletak pada meridian kesepakatan $141^{\circ} 011^{\prime} 10^{\prime \prime}$ BT. Pergeseran posisi monumen meridian batas untuk komponen bujur maupun lintang bervariasi untuk setiap monumen meridian batas sebagaimana terlihat pada tabel 7.

Nilai pergeseran negatif untuk komponen bujur menunjukkan pergeseran kearah barat dari monumen meridian batas hasil survei CBDRF 2004 terhadap monumen meridian batas kesepakatan. Sedangkan nilai pergeseran yang negatif. Untuk komponen lintang menunjukkan pergeseran kearah utara dari monumen 
meridian batas hasil survei CBDRF 2004 terhadap monumen meridian batas kesepakatan.

Tabel 7 Pergeseran monumen meridian batas MM12.1 sampai MM14A berdasarkan perbandingan asumsi (a) dengan asumsi (b).

\begin{tabular}{|c|c|c|c|c|}
\hline \multirow[t]{2}{*}{ No Titik } & \multicolumn{2}{|c|}{ Koordinat Geodetik (WGS84) } & \multicolumn{2}{|c|}{$\begin{array}{c}\text { Koordinat Proyeksi UTM } \\
\text { (Zone 54S) }\end{array}$} \\
\hline & $\Delta$ Lintang & $\Delta$ Bujur & $\begin{array}{c}\Delta \text { northing } \\
\text { (meter) }\end{array}$ & $\begin{array}{l}\Delta \text { Easting } \\
\text { (meter) }\end{array}$ \\
\hline MM12.1 & $-0.6592 ”$ & $-0.7290 ”$ & -20.242 & -22.312 \\
\hline MM12.2 & $-1.6303 ”$ & $-0.7297 ”$ & -50.064 & -22.333 \\
\hline MM12.3 & $-1.5437 ”$ & $-0.7618^{\prime \prime}$ & -47.410 & -23.313 \\
\hline MM12.4 & $-1.1410 "$ & $-0.8537^{\prime \prime}$ & -35.037 & -26.121 \\
\hline MM12.5 & $-1.3437^{\prime \prime}$ & $-0.8819 ”$ & -41.267 & -26.980 \\
\hline MM12.6 & $-0.0242 "$ & $-0.8972 ”$ & -0.749 & -27.450 \\
\hline MM13 & $-2.3417 ”$ & $-1.0271 ”$ & -71.914 & -31.402 \\
\hline MM13.1 & $-1.7824 "$ & $-0.5776 ”$ & -54.737 & -17.650 \\
\hline MM13.2 & $-1.6213^{\prime \prime}$ & $-0.4918^{\prime \prime}$ & -49.790 & -15.028 \\
\hline MM13.3 & $-0.8616 ”$ & $-1.5049 ”$ & -26.467 & -45.962 \\
\hline MM14A & $-2.0490 "$ & $0.6517 ”$ & -62.930 & 19.895 \\
\hline
\end{tabular}

\section{b. Asumsi (a) dengan asumsi (c)}

Dengan menggunakan nilai komponen defleksi vertikal model EGM96, monumen meridian batas MM12.1 sampai MM14A hasil survei CBDRF 2004 tidak terletak pada meridian astronomis kesepakatan yakni $141^{\circ} 01$ ' $10^{\prime \prime}$ BT. Pergeseran posisi monumen meridian batas untuk komponen bujur maupun lintang bervariasi untuk setiap monumen meridian batas sebagaimana terlihat pada tabel 8. Nilai pergeseran yang negatif pada komponen bujur dan lintang menunjukkan pergeseran kearah barat dan utara dari monumen meridian batas hasil survei CBDRF 2004 terhadap monumen meridian batas kesepakatan

Tabel 8 Pergeseran monumen meridian batas MM12.1 sampai MM14A berdasarkan perbandingan asumsi (a) dengan asumsi (c).

\begin{tabular}{|c|c|c|c|c|}
\hline \multirow[t]{2}{*}{ No Titik } & \multicolumn{2}{|c|}{ Koordinat Geodetik (WGS84) } & \multicolumn{2}{|c|}{$\begin{array}{c}\text { Koordinat Proyeksi UTM } \\
(\text { Zone } 54 \mathrm{~S})\end{array}$} \\
\hline & $\Delta$ lintang & $\Delta$ Bujur & $\begin{array}{c}\Delta \text { Northing } \\
\text { (meter) }\end{array}$ & $\begin{array}{l}\Delta \text { Easting } \\
\text { (meter) }\end{array}$ \\
\hline MM12.1 & $-4.269^{\prime \prime}$ & $-3.344 ”$ & -131.094 & -102.357 \\
\hline MM12.2 & $-5.192 "$ & $-3.410 "$ & -159.452 & -104.351 \\
\hline MM12.3 & $-5.063 ”$ & $-3.492 ”$ & -155.479 & -106.880 \\
\hline MM12.4 & $-4.558^{\prime}$ & $-3.675^{\prime}$ & -139.966 & -112.451 \\
\hline MM12.5 & $-4.646 ”$ & $-3.734 ”$ & -142.682 & -114.248 \\
\hline MM12.6 & $-3.287^{\prime \prime}$ & $-3.735^{\prime \prime}$ & -100.938 & -114.264 \\
\hline MM13 & $-5.391 ”$ & $-3.215^{\prime \prime}$ & -165.549 & -98.295 \\
\hline
\end{tabular}




\begin{tabular}{|l|l|l|l|l|}
\hline MM13.1 & $-4.688^{\prime}$ & $-1.669 ”$ & -143.967 & -51.003 \\
MM13.2 & $-4.563 ”$ & $-0.575^{\prime}$ & -140.120 & -17.579 \\
MM13.3 & $-3.657 ”$ & $-1.512 ”$ & -112.306 & -46.160 \\
MM14A & $-4.795 ”$ & $-0.002 ”$ & -147.243 & -0.058 \\
\hline
\end{tabular}

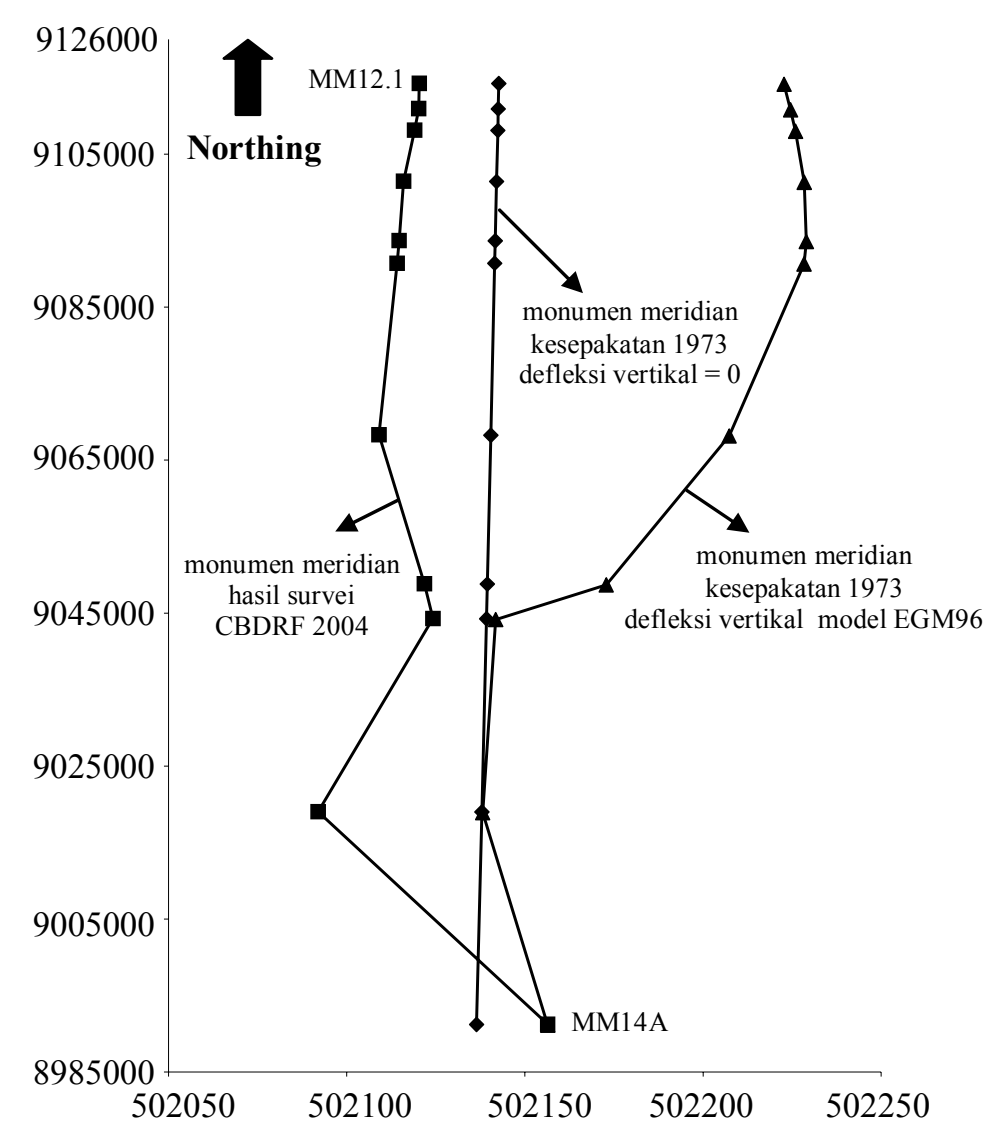

Gambar 6 Grafik pergeseran titik-titik batas MM21.1-MM14A wilayah berdasarkan perbandingan asumsi (a), asumsi (b) dan asumsi (c).

\subsection{Menghitung Perubahan Luas Batas Wilayah}

Pergeseran-pergeseran koordinat dari monumen meridian batas dalam komponen lintang dan bujur berpengaruh kepada perubahan luas batas wilayah Indonesia dan Papua New Guinea. Perubahan luas wilayah dari perbandingan masing-masing asumsi seperti terlihat pada tabel 9. 
Tabel 9 Perubahan luas wilayah berdasarkan perbandingan asumsi (a), (b) dan (c).

\begin{tabular}{|l|l|}
\hline \multicolumn{1}{|c|}{ Perbandingan Asumsi } & \multicolumn{1}{c|}{ Luas Wilayah } \\
\hline Perbandingan asumsi a dan asumsi b & $\begin{array}{l}\text { Luas area } \mathrm{I}=3,016 \mathrm{Km}^{2} \\
\text { Luas area II }=0.0849 \mathrm{Km}^{2}\end{array}$ \\
\cline { 2 - 2 } & Total (area I- area II $)=3,100 \mathrm{Km}^{2}$ \\
\hline Perbandingan asumís a dan asumi c & Luas area I $=8,031 \mathrm{Km}^{2}$ \\
\cline { 2 - 2 } & Total $=8,031 \mathrm{Km}^{2}$ \\
\hline
\end{tabular}

\section{Kesimpulan dan Saran}

a. Permasalahan penegasan batas wilayah darat Indonesia dan Papua New Guinea dapat dikelompokkan dalam dua permasalahan pokok yaitu:

1) Permasalahan pokok berkaitan dengan delimitasi, delimitasi batas antara Indonesia dan Papua New Guinea yang mengacu kepada traktat 1895 dan perjanjian tahun 1973 tidak secara tegas mencatumkan implementasi datum dan kerangka referensi yang digunakan dalam rekonstruksi monumen meridian batas berdasarkan meridian yang disepakati.

2) Permasalahan pokok berkaitan dengan demarkasi, demarkasi monumen meridian batas dilapangan dilaksanakan menggunakan datum dan kerangka referensi yang berbeda yaitu datum kerangka referensi astronomis dan geodetik. Demarkasi monumen meridian tidak dilakukan secara langsung diatas monumen meridian batas untuk merekonstruksi meridian kesepakatan tetapi menggunakan titik-titik bantu astronomis dan godetik serta dilakukan staking out menggunakan poligon.

b. Implikasi dari permasalahan pokok berkaitan dengan demarkasi monumen meridian batas tersebut diatas adalah sebagai berikut:

1) Koordinat geografis asronomis monumen meridian (MM) yang diperoleh dari penentuan posisi astronomis mempunyai ketelitian yang tidak homogen dimana nilai ketelitian tersebut berkisar pada level \pm 8 sampai \pm 30 meter sedangkan bagi monumen meridian perapatan (MMx.y) yang ditetapkan dengan penentuan posisi Transit Doppler mempunyai ketelitian \pm 5 sampai \pm 10 meter dan dapat mencapai \pm 20 sampai \pm 30 meter. Koordinat geografis astronomis monumen meridian perapatan (MMx.y) akan mempunyai ketelitian lebih buruk mengingat interpolasi linear komponen defleksi vertikal dengan metode astrogeodetik dan rotasi dari komponen bujur datum geodetik Transit Doppler NSWC 9Z-3D. Pengaruh ketelitian komponen defleksi vertikal berada pada level \pm 60 sampai \pm 90 meter, oleh karenanya koordinat 
geografis astronomis monumen meridian perapatan (MMx.y) secara kuantitatif mempunyai ketelitian pada level tersebut yang secara spasial tidak homogen. Ketelitian koordinat geografis astronomis dari monumen meridian batas (MM) dan perapatannya (MMx.y) dipengaruhi pula oleh ketelitian rekonstruksi menggunakan metode poligon yang berkisar pada level \pm 9 meter.

2) Oleh karena pengaruh ketelitian tersebut koordinat geografis astronomis monumen meridian batas tidak terletak pada meridian $141^{\circ} 00^{\prime} 00^{\prime \prime} \mathrm{BT}$ dan $141^{\circ} 01^{\prime} 10^{\prime \prime}$ BT sehingga menyebabkan adanya pergeseran dan perubahan luas wilayah kawasan perbatasan.

c. Hasil pengolahan data menggunakan data survei CBDRF tahun 2004 dengan solusi alternatif mempertahankan keberadaan monumen meridian batas meliputi monumen batas MM12.1, MM12.2, MM12.3, MM12.4, MM12.5, MM12.6, MM13, MM13.1, MM13.2, MM13.3 dan MM14A menunjukkan pergeseran posisi monumen meridian batas dan perubahan luas wilayah kawasan perbatasan bila dibandingkan dengan solusi mempertahankan koordinat monumen batas pada meridian $141^{\circ} 01$ ' $10^{\prime \prime}$ BT berdasarkan perjanjian tahun 1973. Hal tersebut berarti posisi fisik dari monomen meridian MM12.1, MM12.2, MM12.3, MM12.4, MM12.5, MM12.6, MM13, MM13.1, MM13.2, MM13.3 dan MM14A tidak terletak pada meridian kesepakatan $141^{\circ} 01$ ' $10^{\prime \prime}$ BT berdasarkan perjanjian tahun 1973.

d. CBDRF dapat digunakan sebagai alternatif solusi bagi penyelesaian permasalahan teknis batas darat wilayah Indonesia dan Papua New Guinea dengan beberapa pertimbangan teknis sebagai berikut:

1) CBDRF memberikan sistem dan kerangka referensi koordinat geodetik global (WGS84/ITRF2000) yang seragam dan konsisten sehingga dapat berguna dalam penataan dan pengawasan kawasan perbatasan.

2) Rekonstruksi titik-titik batas dengan menggunakan CBDRF memberikan tingkat ketelitian penentuan posisi titik-titik batas dalam level yang dapat diandalkan untuk kualifikasi penentuan posisi titik-titik batas wilayah.

e. Dalam kerangka efisiensi serta optimalisasi penataan dan pengawasan kawasan perbatasan, rencana pengadaan datum dan kerangka referensi batas bersama (CBDRF) menggunakan datum WGS84 dan kerangka ITRF2000 perlu segera diadopsi dan diaplikasikan.

f. Perlu dilakukan analisis lebih lanjut bagi monumen meridian batas yang berada di segmen utara agar didapatkan sebuah kesimpulan yang lebih baik bagi penyelesaian permasalahan teknis batas darat Indonesia dan Papua 
New Guinea dalam kerangka optimalisasi penataan dan pengawasan kawasan perbatasan.

\section{Daftar Pustaka}

1. Andreas, H., Komunikasi Pribadi, Staf Pengajar pada Departemen Teknik Geodesi ITB, April 2005.

2. BKPKD, Situs dari Badan Perbatasan dan Kerjasama Daerah http://www.papua.go.id/bkppkd/LksPilarBats.htm, 5 Juli 2005.

3. Heiskanen, W. H. \& Moritz, H., Physical Geodesy, Freeman, San Fransisco 1967.

4. NASA/GSFC, Situs dari NASA/GSFC Laboratory for Terrestrial Physics,Greenbelt,Maryland,http://cddisa.gsfc.nasa.gov/926/egm96/egm9 6.html, 10 Juli 2005.

5. NIMA, Technical Report NIMA TR8350.2 Department of Defense of USA, World Geodetic System 1984 Its Definition and Relationships with Local Geodetic Systems, Third Editoin, 2000.

6. Prijatna, K., Komunikasi Pribadi, Staf Pengajar pada Departemen Teknik Geodesi ITB, April 2005.

7. Rais, J., The Boundary Between Indonesia and Papua New Guinea, 1988, Unpublished Paper.

8. Rais, J. \& Villanueva, K., Towards A RI-PNG Border Common Datum, 1993, Unpublished Paper.

9. Soenarjo, J., Pengabdian, Teknik Geodesi ITB, Bandung, 1978.

10. Torge, W., Geodesy, Second Edition, de Gruyter, Berlin, 1991.

11. Vanicek, P \& Krakiwsky, E. W., Geodesy the Concepts, Second edition, Elsevier, Amsterdam, 1986. 